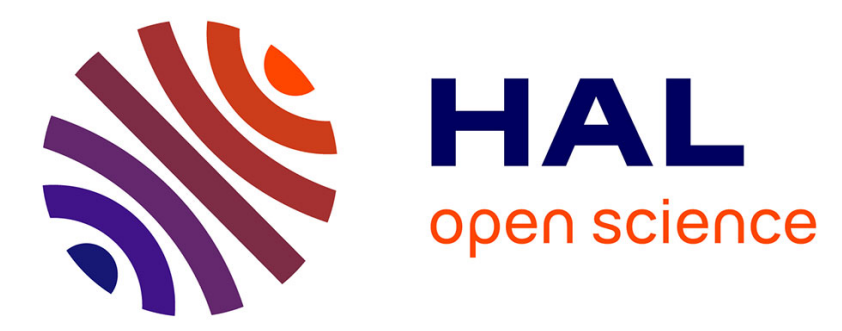

\title{
Effects of settling organic matter on the bioaccumulation of cadmium and BDE-99 by baltic sea benthic invertebrates
}

Maria H. Thorsson, Jenny E. Hedman, Clare Bradshaw, Jonas S. Gunnarsson, Michael Gilek

\section{To cite this version:}

Maria H. Thorsson, Jenny E. Hedman, Clare Bradshaw, Jonas S. Gunnarsson, Michael Gilek. Effects of settling organic matter on the bioaccumulation of cadmium and BDE-99 by baltic sea benthic invertebrates. Marine Environmental Research, 2008, 65 (3), pp.264. 10.1016/j.marenvres.2007.11.004. hal-00501928

\section{HAL Id: hal-00501928 \\ https://hal.science/hal-00501928}

Submitted on 13 Jul 2010

HAL is a multi-disciplinary open access archive for the deposit and dissemination of scientific research documents, whether they are published or not. The documents may come from teaching and research institutions in France or abroad, or from public or private research centers.
L'archive ouverte pluridisciplinaire HAL, est destinée au dépôt et à la diffusion de documents scientifiques de niveau recherche, publiés ou non, émanant des établissements d'enseignement et de recherche français ou étrangers, des laboratoires publics ou privés. 


\section{Accepted Manuscript}

Effects of settling organic matter on the bioaccumulation of cadmium and BDE-99 by baltic sea benthic invertebrates

Maria H. Thorsson, Jenny E. Hedman, Clare Bradshaw, Jonas S. Gunnarsson, Michael Gilek

PII:

S0141-1136(07)00140-7

DOI: 10.1016/j.marenvres.2007.11.004

Reference: MERE 3155

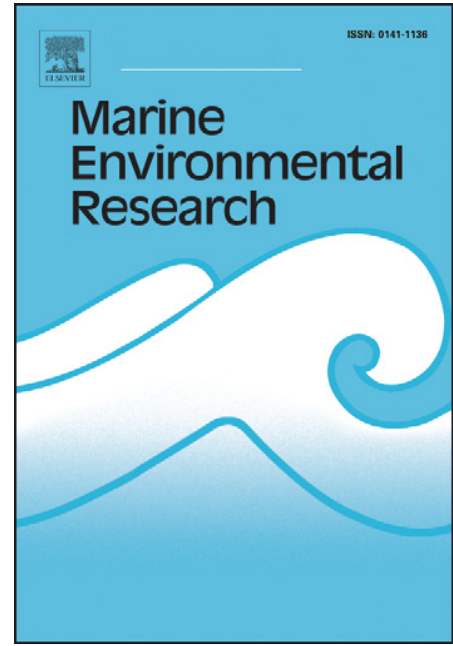

To appear in:

Marine Environmental Research

Received Date:

16 April 2007

Revised Date:

7 November 2007

Accepted Date:

12 November 2007

Please cite this article as: Thorsson, M.H., Hedman, J.E., Bradshaw, C., Gunnarsson, J.S., Gilek, M., Effects of settling organic matter on the bioaccumulation of cadmium and BDE-99 by baltic sea benthic invertebrates, Marine Environmental Research (2007), doi: 10.1016/j.marenvres.2007.11.004

This is a PDF file of an unedited manuscript that has been accepted for publication. As a service to our customers we are providing this early version of the manuscript. The manuscript will undergo copyediting, typesetting, and review of the resulting proof before it is published in its final form. Please note that during the production process errors may be discovered which could affect the content, and all legal disclaimers that apply to the journal pertain. 


\title{
EFFECTS OF SETTLING ORGANIC MATTER ON THE BIOACCUMULATION OF CADMIUM AND BDE-99 BY BALTIC SEA BENTHIC INVERTEBRATES
}

\author{
MARIA H. THORSSON ${ }^{1,2}$, JENNY E. HEDMAN ${ }^{2}$, CLARE BRADSHAW ${ }^{1,2}$, \\ JONAS S. GUNNARSSON ${ }^{2}$ and MICHAEL GILEK ${ }^{1, *}$ \\ ${ }^{1}$ School of Life Sciences, Södertörn University College, SE-141 89 Huddinge, Sweden \\ ${ }^{2}$ Department of Systems Ecology, Stockholm University, SE-106 91 Stockholm, Sweden
}

\begin{abstract}
Settling organic matter $(\mathrm{OM})$ is the major food source for heterotrophic benthic fauna. The high sorption affinity of many contaminants for $\mathrm{OM}$ implies that $\mathrm{OM}$ can influence both the distribution and bioavailability of contaminants. Here, we experimentally examine the role of settling OM of various nutritional qualities on the bioaccumulation of cadmium and the flame retardant BDE-99 by three benthic invertebrates; Macoma balthica, Monoporeia affinis and Marenzelleria sp. Contaminants were associated with three types of OM; a microalgae (Tetraselmis spp.), lignin and sediment. Bioaccumulation of Cd was proportional to OM nutritional quality for all three species, and was species-specific in the order Marenzelleria $>$ M. balthica $>$ M. affinis. BDE-99 bioaccumulation was highest in the treatment with the most nutritious OM (Tetraselmis). Consequently, both benthic species composition and the nutritive value of organic matter settling to the seafloor can have a substantial effect on the bioaccumulation of both metals and organic contaminants.
\end{abstract}

Keywords: Bioavailability, Benthos, Deposit feeding, Food quality, Flame retardant, Heavy metal, Sediment pollution, Monoporeia affinis, Macoma balthica, Marenzelleria

Corresponding author: michael.gilek@ sh.se, +46-8-608 4862 (phone), +46-8-608 4510 (fax) 


\section{Introduction}

Settling organic matter (OM) plays a major role in coastal marine ecosystems as it is the major food source for heterotrophic benthic organisms below the photic zone. Furthermore, a high sorption affinity of most hydrophobic organic contaminants (HOCs) and metals for organic matter implies that $\mathrm{OM}$ can also play a major role in the distribution and bioavailability of contaminants (Lee, 2002, Schlekat et al., 2002). The Baltic Sea is characterized by spatial and temporal differences (both annually and over longer periods owing to eutrophication and climate change) in the amount and type of OM settling to the seafloor. For example, labile organic matter from diatoms and other phytoplankton species reaches the sediment following the annual spring bloom, whereas detritus from cyanobacteria blooms may settle during summer. Other sources of OM to benthic deposit-feeders are resuspended sediment introduced by current and storm events and allochthonous material such as products from terrestrial plants, both of which are generally of lower nutritional quality for deposit-feeding benthic animals. Due to this variation in the quality of the settling OM, it is of great interest to assess how bioaccumulation of contaminants by benthic deposit-feeders is affected by different types of OM inputs.

According to the equilibrium partitioning theory (EPT) bioaccumulation of hydrophobic organic contaminants (HOCs) is inversely proportional to the total organic carbon (TOC) content of the sediment (Lake et al., 1990). However, the EPT theory does not consider either the nutritional quality of the sediment or the feeding strategy of benthic organisms (Gunnarsson et al., 1999a). Several studies have shown that bioaccumulation of HOCs by deposit-feeding benthic animals instead can increase with increasing TOC content of the sediment and reach tissue concentrations well above those predicted by EPT (Gunnarsson et al., 1996; Gunnarsson and Sköld, 1999). In addition, not only may the bioaccumulation of HOCs be proportional to TOC quantity but also to its nutritional quality (Gunnarsson et al 1999a, Granberg and Forbes 2006). Gunnarsson et al (1999a) suggested that when a significant part of the sediment TOC is composed of labile organic matter, the nutritious organic particles may act as vectors of contaminant exposure and increase the uptake of sediment-associated contaminants through their diet. On the other hand, if the sediment TOC is mostly refractory it may act as a dilution matrix and decrease the bioavailability of sediment-associated contaminants. The quality of OM may also affect the sorption kinetics of contaminants to TOC (Kukkonen et al., 2003) and thereby affect the assimilation and bioavailability of OM-associated contaminants to deposit feeders. Bioaccumulation of metals, on the other hand, is more dependent on physico-chemical variables (e.g. chemical speciation, acid volatile sulfides (AVS), salinity, $\mathrm{pH}$, redox conditions) than on TOC alone (Griscom and Fisher, 2004) and consequently, steady state models, such as the free ion activity model (FIAM) and the 
biotic ligand model (BLM) for metals are more complicated than the EPT (Luoma and Rainbow, 2005). Nevertheless, since many metals partition preferentially to OM particles (Schlekat et al., 2002), organic matter is also of great significance for the bioavailability and hence bioaccumulation of metals. For example, an increased assimilation efficiency and bioavailability of the metal Cd with increased nutritional OM quality has been observed (Maloney, 1996; Wang and Wong, 2003). The failure of many bioaccumulation models to accurately predict the bioaccumulation of HOCs and metals by detritus-feeding organisms highlights the importance of other factors, such as the feeding ecology and physiology of the organisms. Most deposit feeders are selective feeders (Jumars and Wheatcroft, 1989), which means that they selectively choose and ingest nutritious particles such as algal cells, bacteria, and different types of detrital matter (Lopez and Levinton, 1987). This means that contaminant exposure and subsequent bioaccumulation can vary substantially among different species inhabiting the same sediment. Animal morphology as well as physiological and biochemical properties of the digestive system have also been shown to influence the bioavailability of sediment-associated contaminants (Mayer et al., 1996; Chen and Mayer, 1999; Mayer et al., 2001).

The benthic fauna in the Baltic Sea are dominated by only a few invertebrate species. Among the most common are the three species investigated in this study: the deposit-feeding amphipod Monoporeia affinis, which burrows in the top-most $5 \mathrm{~cm}$ of the sediment (Ankar, 1977), but feeds mainly on surface sediments (Byrén et al., 2002); the facultative deposit-feeding clam Macoma balthica, which lives buried a few centimeters down in the sediment and primarily feeds on organic particles deposited on the sediment surface; and the invasive polychaete worms Marenzelleria spp. (Zettler, 1995) which are also generally considered to be surface deposit feeders (Dauer et al., 1981). Although the ecology of the Baltic benthic food web is relatively well understood (Elmgren and Hill, 1997; Ejdung et al., 2000), the influence of sedimentary organic matter quality on contaminant bioaccumulation by benthic invertebrates is to our knowledge not yet described. In particular, there is a lack of knowledge on how the recent invasion of the polychaete genus Marenzelleria spp. will influence trophic transfer of sedimentassociated contaminants.

In the present experiment, we investigated how the deposition of $\mathrm{OM}$ of various nutritional qualities (the unicellular green algae Tetraselmis spp., lignin and surface sediment) on the sediment surface affected contaminant bioaccumulation by the three benthic deposit-feeding invertebrates described above. The various OM were spiked with two radio-labeled contaminants: a) the metal cadmium $\left({ }^{109} \mathrm{Cd}\right)$; b) a polybrominated diphenyl ether $\left({ }^{14} \mathrm{C}-\mathrm{BDE}-99\right)$ and added to 
microcosms to simulate a field situation where different types of $\mathrm{OM}$ often reach the sediment surface in pulse events. By simultaneously investigating the bioaccumulation of both a metal and a hydrophobic organic contaminant, we strived for a more general understanding on how $\mathrm{OM}$ influences contaminant bioaccumulation by benthic deposit-feeders. It was hypothesized that bioaccumulation would increase with the nutritional quality of the OM (Tetraselmis $>$ sediment $>$ lignin) and that this effect would be more pronounced for BDE-99, owing to an assumed higher sorption affinity to OM for BDE-99 than for cadmium (Turner and Millward, 2002). Prior knowledge of the feeding ecology and physiology of the investigated benthic animals did not, however, permit any a priori hypotheses of bioaccumulation differences among species. Instead we speculated that biological factors such as selective feeding, digestive solubilization of contaminants, burrowing behavior and lipid content could interact to generate differences among the investigated animals both in terms of differences in contaminant bioaccumulation as well as in how OM influences bioaccumulation.

\section{Materials and methods}

\subsection{Experimental design}

The experiment had a two-factorial design with 1) organic matter (OM) and 2) animals as fixed factors, both of which had 3 levels. The levels for the factor 'OM' were: a) the unicellular green algae Tetraselmis spp. (hereafter referred to as Tetraselmis), b) surface sediment and c) lignin wood fibers. The levels for the factor 'animals' were: a) Monoporeia affinis b) Macoma balthica and c) Marenzelleria. In addition, there was one negative control treatment with added Tetraselmis algae but no contaminants for each animal species, in order to verify that the contaminants had no effects on animal survival or biomass. Each treatment had three replicate experimental sediment core tubes giving a total of 36 core tubes.

\section{$2.2 \quad$ Field sampling}

\subsubsection{Collection of animals}

Adult Monoporeia affinis were collected with a Van Veen grab at a depth of $36 \mathrm{~m}$ in the Baltic Sea, in Hållsfjärden $\left(58^{\circ} 48.59^{\prime} \mathrm{N}, 1^{\circ} 36.31^{\prime}\right.$ E) near the Askö Laboratory on the $28^{\text {th }}$ of January 2004. Macoma balthica were collected with a benthic sledge (Blomqvist and Lundgren, 1996) at 30-31m depth in Hållsfjärden (58 $49.72^{\prime} \mathrm{N}, 1^{\circ} 32.26^{\prime} \mathrm{E}$ and $\left.58^{\circ} 49.78^{\prime} \mathrm{N}, 17^{\circ} 32.13^{\prime} \mathrm{E}\right)$ on the $20^{\text {th }}$ of January 2004. Clams with a shell length of c. $2 \mathrm{~cm}$ were sorted out for use in the 
experiment. Monoporeia and Macoma were kept (each species separately) in $30 \mathrm{~L}$ buckets in sieved $(1 \mathrm{~mm})$ sediment and aerated brackish water $\left(4^{\circ} \mathrm{C}\right)$ prior to the experiment. Marenzelleria were collected on the $21^{\text {st }}$ of January 2004 off the island of Mörkö, $40 \mathrm{~km}$ south of Stockholm $\left(59^{\circ} 2.29^{\prime} \mathrm{N}, 17^{\circ} 41.45^{\prime} \mathrm{E}\right)$ at a depth of approximately $1 \mathrm{~m}$. Recent population genetic studies have indicated that there are at least three different (but physiologically very similar) species of Marenzelleria in the Baltic Sea (Bastrop and Blank, 2006). The worms used in this study were not identified to the species level, hence we refer to them as Marenzelleria. Sediment was taken from $1 \mathrm{~m}$ depth using a shovel and the worms were sieved out on site using a 1mm-mesh sieve. Worms with a mean length of c. $5 \mathrm{~cm}$ were retained for the experiment. The worms were brought to the lab and kept in a mixture of sandy and muddy surface sediment (1:1 on a volume basis) in $30 \mathrm{~L}$ aquaria with aerated brackish water $\left(4^{\circ} \mathrm{C}\right)$ in order to acclimatize to the surface sediment used in the experiment. All brackish water (6.4 - $6.7 \mathrm{psu})$ used in the experiment was collected at the Askö Marine Laboratory at approximately $15 \mathrm{~m}$ depth and sieved through a sand filter.

\subsubsection{Collection of sediment}

Surface sediment (top 3-5 cm) was collected in December 2003 from a depth of $45 \mathrm{~m}$ using a benthic sledge (Blomqvist and Lundgren, 1996) at Asenskallen (58 46.5' $\left.\mathrm{N}, 17^{\circ} 41.4^{\prime} \mathrm{E}\right)$ in the vicinity of the Askö Laboratory. The sediment was sieved (without addition of extra water) through a $1 \mathrm{~mm}$ mesh into $30 \mathrm{~L}$ buckets to remove macrofauna without losing fine-grained sediment particles and micro- and meiofauna. It was then left to settle during two months in the dark with overlying aerated brackish water in a cold room at $4{ }^{\circ} \mathrm{C}$.

\subsection{Experimental procedures}

\subsubsection{Preparation of core tube microcosms}

Kajak core tubes with an inner diameter of $8 \mathrm{~cm}$ and height $50 \mathrm{~cm}$ were carefully inserted by hand in the buckets with the aged surface sediment. The tubes were then filled to the top with brackish Baltic water, carefully in order to minimize resuspension. A rubber stopper was inserted at the top and the cores were pulled out of the bucket, retaining the sediment by vacuum. Another rubber stopper was inserted in the bottom of the tubes and they were placed in holding racks in a thermoconstant room kept at $4{ }^{\circ} \mathrm{C}$ during the entire experiment. The microcosms had a sediment column of approximately $30 \mathrm{~cm}$ height $(1500 \mathrm{ml})$ and a water column of approximately $17 \mathrm{~cm}$ $(850 \mathrm{ml})$. Aeration was provided to each core tube by gently bubbling air through glass tubes inserted through the top stoppers. Two other glass tubes were inserted through the top-stoppers, 
one as an outlet for excess air, the other to take samples from the water column during the experiment. The core tubes were kept aerated in the dark at $4{ }^{\circ} \mathrm{C}$ for 5 weeks before the animals and spiked organic matter were added.

\subsubsection{Addition of animals}

On March 2, 2004, the animals were sieved out from their storage sediment and added to the core tubes. For Marenzelleria, only individuals with head and visible feeding palps were retained for the experiment. Female Monoporeia with visible embryos were not used since their life cycle ends after breeding. All animals were added to represent average field densities common in the Baltic Sea. Therefore, the number of individuals as well as the biomass differed between animal treatments (Table 1). The choice to perform the experiment at average field densities was taken to increase the ecological relevance of the study to the field situation. Most individuals burrowed into the sediment within 5 minutes. Individuals that had not burrowed into the sediment after $24 \mathrm{~h}$ (two Marenzelleria and four Macoma) were replaced with new individuals. The tubes were placed randomly in the thermoconstant room $\left(4{ }^{\circ} \mathrm{C}\right)$ and kept with a green light/dark cycle of $12: 12 \mathrm{hrs}$.

\subsubsection{Contaminants}

Two radiolabeled contaminants were used in the experiment: ${ }^{14} \mathrm{C}$-labeled BDE-99 $\left(2,2,4,4^{\prime}, 5-\right.$ pentabromodiphenyl ether) in acetone (synthesized by the Dept. of Environmental Chemistry, Stockholm University, Sweden), with a specific activity of $3.2 \mathrm{kBq} . \mu \mathrm{g}$ BDE-99 $9^{-1}$ and a $\log K_{\mathrm{ow}}$ of 7.13 (Tittlemier et al., 2002); and ${ }^{109} \mathrm{Cd}$ in $0.1 \mathrm{M} \mathrm{HCl}$ (Amersham), with a specific activity of 24 MBq. $\mu \mathrm{g} \mathrm{Cd}{ }^{-1}$. All measured ${ }^{109} \mathrm{Cd}$ activities were corrected for radioactive decay as of March 1 , 2004.

\subsubsection{Organic matter sources}

For the organic enrichment, three different types of organic matter were used: 1) Tetraselmis (Reed Mariculture, Inc. San Jose, CA, USA), a highly nutritious unicellular green alga; 2) lignin, i.e. terrestrial wood fibers, a biproduct from paper manufacture called Curan 100, (Holmen Paper $\mathrm{AB}$, Sweden); and 3) surface sediment (i.e. the same sediment as used in the experiment). The different types represented a high (Tetraselmis), low (sediment) and very low (lignin) nutritious quality organic matter source to the benthic invertebrates. The quality is here referred to as the nutritious value of the organic matter source defined by the relative amount of total nitrogen (TN) 
to total carbon (TC) in the organic matter, and the amounts of amino acids and fatty acids (Gunnarsson et al., 1999a). Biochemical characteristics measured (see method below) and used for the definition of quality of the three organic matter sources are presented in Table 2. Tetraselmis is a readily assimilated labile carbon source, i.e. rich in fatty acids and amino acids and highly palatable to marine detritivores and used as feed in aquaculture (http://www.reedmariculture.com/microalgae/tetraselmis.asp), while lignins consist of unpalatable refractory aromatic phenolic polymers (e.g. Gunnarsson et al., 1999a). Finally, the surface sediment consists of a mixture of organic and inorganic particles of various types and origins. The OM in sediment varies in quality with time. For example, after spring blooms, highly nutritious phytoplankton cells settle to the sediment surface and provide most of the energy to benthic heterotrophs. This $\mathrm{OM}$ is then progressively processed and degraded by infaunal organisms until most of it is refractory. In the present study the sediment was collected in early winter, hence its nutritious quality was relatively low.

\subsubsection{Spiking of organic matter sources and addition to the cores}

A concentrate of thawed Tetraselmis algae was washed with filtered brackish water and centrifuged 5 times for $20 \mathrm{~min}$ at $5000 \mathrm{rpm}$ to remove as much dissolved organic matter as possible, leaving a suspension of intact non-living algal cells. Dry powdered lignin (Curan 100, Holmen paper $\mathrm{AB}$, Sweden), was resuspended and mixed in filtered brackish water. The suspension was then centrifuged and rinsed 5 times, for $15 \mathrm{~min}$ at $5000 \mathrm{rpm}$ and the dissolved and very fine particles in the supernatant were removed. Surface sediment, i.e. the same sediment as was used to fill the core tubes, was mixed into a slurry and used as the third organic organic matter source. The amount of each OM type to add to the cores was calculated to provide a final nominal enrichment of $0.05 \mathrm{~g} \mathrm{dw}$ organic carbon per core (see Table 2). This corresponds to $10 \mathrm{~g}$ $\mathrm{dw}$ organic carbon $\mathrm{m}^{-2}$, which is a typical amount of organic carbon that settles on the Baltic seabed following a spring bloom (Larsson et al., 1986). Thus the total mass and volume of each OM source added to the cores were different but each core received the same amount of TOC.

Radiolabeled BDE $\left({ }^{14} \mathrm{C}\right.$-BDE-99) and the radioisotope ${ }^{109} \mathrm{Cd}$ were combined with each of the preweighed organic matter sources to produce a spiked stock. The amounts of ${ }^{14} \mathrm{C}-\mathrm{BDE}$ and ${ }^{109} \mathrm{Cd}$ were calculated to give a final nominal activity per core of $27 \mathrm{kBq}(8.4 \mu \mathrm{g}) \mathrm{BDE}$ and $118 \mathrm{kBq}$ (4.9 ng) Cd per core. These concentrations were chosen to be detectable but at or below reported NOEC values. No difference in survival, biomass or visual observations of feeding and swimming activity of the animals was observed between cores that were dosed with the 
contaminants and the uncontaminated negative controls. Spiking was done by first adding the stock with ${ }^{14} \mathrm{C}$-BDE-99 to the organic matter source in a glass flask, then adding the ${ }^{109} \mathrm{CdCl}_{2}$ stock. Each spiked OM source was sealed with Parafilm and mixed on a magnetic stirrer at $4{ }^{\circ} \mathrm{C}$ for $48 \mathrm{~h}$ to ensure a thorough mixing and radiolabeling of the organic matter. The spiking time was kept short in order to minimize the degradation of labile OM during the process. The spiked organic materials were then divided into aliquots containing equal amounts of organic carbon (and ${ }^{109} \mathrm{Cd}$ and ${ }^{14} \mathrm{C}-\mathrm{BDE}$ ) for addition to the cores. The aliquots were then added to the overlying water using a glass funnel with its end close to the sediment surface, and the OM was allowed to settle as a thin (1-2 mm) surface layer for $12 \mathrm{~h}$ without aeration. Most of the overlying water was then removed, carefully to avoid resuspension, and replaced with new brackish water in order to remove remaining radioactivity in the water, as the focus of this study was to examine bioaccumulation from sediment exposure, not from the water column. A $10 \mathrm{ml}$ water sample was taken from this removed overlying water in order to estimate the loss of ${ }^{14} \mathrm{C}$-BDE and ${ }^{109} \mathrm{Cd}$ and organic carbon with the water change. A loss of organic matter and associated contaminants was observed. On average $36 \%, 47 \%$ and $2.5 \%$ of the added contaminants were removed from the microcosm in the Tetraselmis, lignin and sediment treatments respectively. Hence comparisons of measured contaminant concentrations in animal tissue are expressed per sediment concentration in the core, using bioaccumulation factors. Following the replacement of the overlying water, the cores were sealed with corks and the experiment was started (day 0). The position of the cores in the thermoconstant room was random with respect to organic matter treatment. The cores were constantly aerated and salinity was monitored once a week (6.4-6.7 PSU throughout the experiment).

\subsection{Collection and preparation of samples}

The experiment was terminated after 34 days. The core tubes were sampled randomly and samples of animals, sediment and water for chemical and radioactivity analyses were taken as described below. First, the water was siphoned off and the sediment was pushed from underneath to the top of the core tube allowing the removal of $1 \mathrm{~cm}$ thick sediment slices. Each core was sliced every centimeter down to $5 \mathrm{~cm}$ and thereafter from 6-7 and 8-9 cm. Treatments with Marenzelleria were also sampled at $14-15 \mathrm{~cm}$ since the worms had visible burrows to this depth. The sampling of sediment slices at different depths was done in order to be able to measure the downward transport of contaminants into the sediment. These results are presented elsewhere (see companion paper by Hedman et al., in press). Animals, samples of feces and samples of the inner linings of visible burrows were collected and put in scintillation vials. The rest of the sediment 
slice was used for sediment and pore water analyses. Recovered animals were kept in aerated brackish water $\left(4^{\circ} \mathrm{C}\right)$ for $24 \mathrm{~h}$ to let them purge their gut from sediment. After gut purging, the animals were frozen at $-20^{\circ} \mathrm{C}$ until analysis.

Preparation of animals for chemical and radioactivity analyses was done by thawing, removing Macoma shells and taking a small composite subsample (17-19 mg ww core $\mathrm{mor}^{-1}$ Macoma, and 2$3 \mathrm{mg}$ ww core $^{-1}$ for Monoporeia and Marenzelleria) for lipid analyses. The remaining animal samples were then dried $\left(24 \mathrm{~h}, 50^{\circ} \mathrm{C}\right)$ in pre-weighed scintillation vials. Dried animal samples were kept at $-20^{\circ} \mathrm{C}$ until analysis.

\subsection{Chemical analyses}

\subsubsection{Radioactivity measurements}

The activity of ${ }^{109} \mathrm{Cd}$ was analyzed first using a gamma spectrometer (Canberra GC 2020 (GA1) and Ortec GEM HPGe-detectors) and then for total radioactive decays (combined ${ }^{109} \mathrm{Cd}$ and ${ }^{14} \mathrm{C}$ BDE) using liquid scintillation counting (LSC) (LKB Wallac Rackbeta 1214). Activities of ${ }^{14} \mathrm{C}$ labeled BDE-99 were calculated by subtracting ${ }^{109} \mathrm{Cd}$ activities (gamma spectrometry) from combined ${ }^{109} \mathrm{Cd}$ and ${ }^{14} \mathrm{C}$-BDE activities (measured with LSC) as described below. For gamma analysis, sample geometry, counting efficiency and background radiation were corrected for using matching standards with a known ${ }^{109} \mathrm{Cd}$ activity. Samples were run until the error of the measurement was less than $10 \%$ (between $10 \mathrm{~min}$ and $4 \mathrm{~h}$ depending on the activity). Counts were adjusted for radioactive decay and normalized to a dry weight basis. Dried animal samples for radioactivity measurements were weighed and then rehydrated for $24 \mathrm{~h}$ with $1 \mathrm{ml}$ de-ionized water and then sonicated for 30 minutes. Gamma measurements were run directly on these rehydrated and sonicated samples. For LSC the animal samples were digested in $1 \mathrm{ml}$ of Soluene (Packard Bioscience) for $24 \mathrm{~h}$ and mixed with $10 \mathrm{ml}$ of scintillation cocktail (Hionic Fluor, Packard Bioscience). Liquid scintillation counting for total radioactive decay $\left({ }^{109} \mathrm{Cd}\right.$ and ${ }^{14} \mathrm{C}$-BDE) was then performed (LKB Wallace Rackbeta 1214) after at least $24 \mathrm{~h}$ in the dark (to avoid chemoluminescence). Sediment samples were prepared in a similar way to the animal samples with the exception that no Soluene was added.

Detection efficiencies for both ${ }^{109} \mathrm{Cd}$ and ${ }^{14} \mathrm{C}$-BDE were calculated from equations derived from a series of standards with known activities and different degrees of color quenching (taking into account background counts). The amount of ${ }^{109} \mathrm{Cd}$ present in the scintillation sample was calculated using the activity per dry weight obtained from the gamma spectrometer, the efficiency 
equation from the scintillation analysis and the weight of the sample. This was then subtracted from the total scintillation counts to obtain the amount of ${ }^{14} \mathrm{C}-\mathrm{BDE}$ in the sample. Concentrations of ${ }^{109} \mathrm{Cd}$ and ${ }^{14} \mathrm{C}$-BDE in the various samples (animals, sediment, feces and burrow linings) were then expressed on a dry weight basis $\left(\mathrm{Bq} \mathrm{g} \mathrm{dw}^{-1}\right)$.

\subsubsection{Other chemical analyses}

Total $\mathrm{C}$ and $\mathrm{N}$ in the sediment were measured in oven-dried samples using a LECO CHNS 932 analyzer. Total organic carbon (TOC) was determined after acidification with $\mathrm{HCl}$ to remove carbonates according to Hedges and Stern (1983). Total lipid content of animals was analyzed by the micro-gravimetric method of Gardner et al. (1985).

\subsection{Calculation of bioaccumulation factors}

Bioaccumulation factors (BAF) after 34 days of exposure were calculated by dividing contaminant concentrations per $\mathrm{g} d \mathrm{w}$ animal by the contaminant concentration per $\mathrm{g} \mathrm{dw}$ sediment in the $0-1 \mathrm{~cm}$ slice of their respective core tube. Lipid and TOC normalized bioaccumulation factors (BSAF) were also calculated for each core tube BSAF $=\left(\mathrm{C}_{\text {animal }} /\right.$ lipid $) /\left(\mathrm{C}_{\text {sediment }} / \mathrm{TOC}\right)$; where $\mathrm{C}_{\text {animal }}=$ animal contaminant concentration $\left(\mathrm{Bq} \mathrm{g} \mathrm{dw}{ }^{-1}\right)$, lipid $=\%$ lipid on a dry weight basis, $\mathrm{C}_{\text {sediment }}=$ sediment $(0-1 \mathrm{~cm})$ contaminant concentration $\left(\mathrm{Bq} \mathrm{g} \mathrm{dw}{ }^{-1}\right)$, and $\mathrm{TOC}=\%$ TOC of sediment on a dry weight basis.

\subsection{Statistical analysis}

Treatment effects, i.e. "OM quality" (3 levels: Tetraselmis, lignin, sediment) and "animal species" (3 levels: Monoporeia, Macoma, Marenzelleria) were tested using two-way analyses of variance (ANOVA) with $\log _{10}$-transformed BAF and BSAF values for $\mathrm{Cd}$ and BDE-99 as dependent variables respectively. The two-way ANOVAs were run separately for Cd and BDE-99. Heterogeneity of variance was checked for using Levene's test. Significant differences among levels within significant main effects were tested for using Tukey's LSD post hoc test. When significant animal vs. OM interactions were detected the Tukey's LSD test was used to separately test for significant differences among treatments within each animal species and OM treatment, respectively. 


\section{Results}

\subsection{Animal activity and recovery}

During the 34-day exposure period clear differences in activity were observed among the three animal species. In cores with amphipods (Monoporeia affinis) the water column was cloudy due to the resuspension of sediment particles caused by swimming activity, and during the whole experiment animals were observed swimming in the water column. The clams (Macoma balthica) and polychaete worms (Marenzelleria) on the other hand did not resuspend as many particles and were instead observed to burrow in the sediment down to $5 \mathrm{~cm}$ and $15 \mathrm{~cm}$, respectively, with a clearly visible oxygenated zone surrounding their burrows. At the end of the experiment $100 \%$ of the Macoma and $42 \%$ of the Monoporeia were recovered alive. The lower recovery of Monoporeia may in part be explained by a lower recapture efficiency for this species. The sediment could not be sieved since it needed to be kept intact for radioactivity analyses, hence it was difficult to find and collect all of the amphipods. Due to the slicing process it was also difficult to collect intact Marenzelleria (many worms were cut in pieces during the sampling); $38 \%$ were found intact and alive. However, based on the number of pieces of worm that were recovered, the survival of Marenzelleria was assumed to be near $100 \%$. There were no significant differences in animal recovery or in average individual dry weights between OM treatments or between any of the contaminated treatments and the negative controls. These results indicate that the animals had sufficient food and good experimental conditions.

\subsection{Contaminant concentrations in sediment and water}

At the end of the experiment most of the added contaminants still remained at the sediment surface (78-95\% and 71-98\% for Cd and BDE-99, respectively). This indicates that animals were exposed to contaminants primarily from the sediment surface and that this exposure was significant throughout the entire exposure period in all treatments. However, although contaminants were added at the same nominal concentrations in all experimental treatments, substantial differences in the contaminant concentrations in surface sediment $(0-1 \mathrm{~cm})$ were observed at the end of the exposure period (Table 3). Surface sediment concentrations of both cadmium and BDE-99 were highest in the treatment with added sediment and no animals. Surface sediment concentrations of both cadmium and BDE-99 were also higher in the Monoporeia treatments compared to the other two animal treatments. These observed differences in sediment concentrations are probably caused by a combination of two factors. First, there was an initial loss of OM-associated contaminants when the overlying water of the microcosms was changed 12 
$\mathrm{h}$ after $\mathrm{OM}$ addition. This initial loss due to water change was lower when the added OM was surface sediment (probably due to its faster settling rate). Secondly, animals affected the distribution of the contaminants in the experimental microcosms through their movement and feeding activity (for more details see the companion paper by Hedman et al., in press). This resulted in both a downward burial and to some extent also an upward remobilization (to the overlying water) of the contaminants. In general, this animal effect on contaminant distribution (i.e. burial below the top $1 \mathrm{~cm}$ ) was higher for Marenzelleria and Macoma $(9.4$ and $7.5 \% \mathrm{Cd}$ burial, respectively) compared to Monoporeia (4.8\% burial).

\subsection{Bioaccumulation factors}

After 34 days of exposure substantial amounts of both Cd and BDE-99 were found in all exposed animals. Contaminant tissue concentrations and bioaccumulation factors are presented in Table 3 and in Fig. 1 and 2). Owing to differences in sediment concentrations that were caused by differences in the experimental treatments (i.e. different losses after the water exchange) contaminant concentrations in animals per se cannot be compared between treatments. However, using bioaccumulation factors allows the normalization of tissue concentrations to the respective sediment concentrations, thereby compensating for differences in sediment concentrations. BAF and BSAF values were hence used to compare bioaccumulation among treatments.

In general, as expected for a hydrophobic organic contaminant, bioaccumulation was substantially higher for BDE-99 $(\mathrm{BAF}=5.4-74.6)$ than for cadmium $(\mathrm{BAF}=0.3-9.2)$ (Table 3). For cadmium, animal tissue concentrations only reached levels higher than those found in the surface sediment (i.e. BAF > 1) in the Tetraselmis treatments. For both cadmium and BDE-99 there were significant differences in bioaccumulation both among the OM treatments (Fig. 1 and 2) and between animal species for cadmium (Fig. 1), but these treatment effects differed between the two contaminants (as described below).

\subsubsection{Effects of settling organic matter on bioaccumulation}

For both contaminants bioaccumulation differed significantly depending on which settling organic matter the contaminant was associated with (Table 3, Fig. 1 and 2). In general, bioaccumulation of both $\mathrm{Cd}$ and BDE-99 was highest in animals exposed to contaminants associated with the $\mathrm{OM}$ with the highest nutritional quality (i.e. Tetraselmis) (Fig. 1 and 2). Thus, for all animal species, the extent of cadmium bioaccumulation was in the order: Tetraselmis $>$ lignin $>$ sediment (ANOVA and Tukey's LSD test, p < 0.0001) (Fig. 1). Expressed as 
percentages, the differences between BAF values for Cd were approximately $244 \%$ higher in the Tetraselmis treatment than in the lignin treatment, and $110 \%$ higher in the lignin treatment than in the surface sediment treatment. For BDE-99, BAF values were in the order Tetraselmis $>$ surface sediment $=$ lignin $($ ANOVA and Tukey's LSD, $\mathrm{p}<0.0001$ ) for Monoporeia and Marenzelleria . Overall, the percentage differences were $511 \%$ between Tetraselmis and surface sediment and 27 $\%$ between surface sediment and lignin. For Macoma, however, the trend was different; they accumulated BDE-99 in the order Tetraselmis > surface sediment $>$ lignin (Tukey's LSD, p < 0.05). Macoma thus differed from the other species in that BDE-99 associated with sediment was bioaccumulated to a higher degree than when associated with lignin. In summary, bioaccumulation of both Cd and BDE-99 by all species was highest in presence of the nutritious green algae Tetraselmis. This Tetraselmis effect was, however, approximately two times more pronounced for the hydrophobic organic contaminant BDE-99 (511\% higher) than for the metal cadmium $(244 \%)$.

\subsubsection{Species-specific differences in bioaccumulation}

For cadmium, there was a significant difference in BAF values between all animals (ANOVA and Tukey's LSD, $\mathrm{p}<0.05$ ), with the highest bioaccumulation in Marenzelleria (BAF $=1.1$ to 9.2), followed by Macoma (BAF $=0.8$ to 4.5) and Monoporeia $(\mathrm{BAF}=0.3$ to 2.4) (Fig. 1). On average Cd bioaccumulation was $49 \%$ higher in Marenzelleria than in Macoma, which in turn exhibited 115\% higher bioaccumulation than Monoporeia. For BDE-99, on the other hand, the differences among species were less apparent, except for in the sediment treatment where a significantly higher bioaccumulation (Tukey's LSD, p<0.05) was observed for Macoma (155\% higher) than for Marenzelleria and Monoporeia (Fig. 2).

Because a large number (62\%) of Marenzelleria were retrieved in pieces owing to the sediment slicing procedure, the majority of the worms may not have been able to purge their guts from contaminated organic matter. Consequently, it is possible that contaminated OM remaining in Marenzelleria guts biased the BAF values presented in Table 3. To test the potential size of this bias we estimated adjusted BAF values of cadmium and BDE-99 in Marenzelleria. These calculations were performed by assuming ingested contaminant concentrations equal to that of surface $(0-1 \mathrm{~cm})$ sediment, a gut capacity of $51 \%$ of dry weight (Bock and Miller, 1999) and that $62 \%$ of the worms had contaminated organic matter in their guts. Although, it is hard to exactly estimate contaminant concentrations in worm guts without actually measuring these, we believe that the assumption of contaminant gut concentrations equal to those of the surface sediment is 
conservative given that contaminant solubilization and subsequent uptake will occur during gut passage. Interestingly, the performed BAF adjustments indicated a potential underestimation of Marenzelleria BAFs based on measured concentrations, rather than the expected overestimation (Table 4). This potential underestimation was in the range of $2-41 \%$ for cadmium and $36-39 \%$ for BDE-99 and was caused by the assumed lower contaminant concentrations of ingested material (on a dry weight basis) than in the remaining worm tissues. Gut purging will therefore lead to higher contaminant concentrations and BAF values in purged worms. Thus, it is not likely that slicing of the worms during sampling has affected the observed species-specific differences in cadmium bioaccumulation. Instead, it is even possible that cadmium bioaccumulation in Marenzelleria has been underestimated with up to $41 \%$. Similarly, there are no reasons to believe that a complete gut purging of Marenzelleria would have changed the observed differences in cadmium and BDE-99 bioaccumulation depending on type of OM (Table 4).

\subsubsection{Lipid and TOC normalization}

BSAF values for BDE-99 ranged from 0.4 to 11.4 in the order Tetraselmis $>$ surface sediment $=$ lignin (Table 3 and Fig. 3) for Monoporeia and Marenzelleria. BSAF for Macoma exposed to contaminated sediment was higher than bioaccumulation by Marenzelleria and by Monoporeia exposed to the same OM source. Hence, normalization to sediment TOC and lipid did not remove the observed differences in bioaccumulation between $\mathrm{OM}$ or animal treatments and these differences must thus be attributed to other factors than equilibration with lipids and TOC.

\section{Discussion}

\subsection{Importance of biological processes for bioaccumulation}

Bioaccumulation of both $\mathrm{Cd}$ and BDE-99 by all three benthic species used in this study was profoundly affected by the quality of the organic matter to which the contaminants were associated. Furthermore, bioaccumulation was species-specific, i.e. both the extent of contaminant bioaccumulation and the effect of OM quality differed between the species. There were also obvious differences in the bioaccumulation pattern of the metal and the HOC. More specifically, there were significant differences between animals for $\mathrm{Cd}$ uptake, but not for the bioaccumulation of BDE-99. 
A common method to compare bioaccumulation of HOCs by benthic deposit-feeders is to assume that the organisms have reached a steady-state with their environment and that HOCs are at equilibrium between the lipids of the animals and the TOC of the sediment, and hence to normalize bioaccumulation factors to the lipid content of the organism and to the TOC content of the sediment (Di Toro et al., 1991). These calculations result in the biota sediment accumulation factor (BSAF), which assumes that the contaminants partition between the sedimentary organic matter and the lipid reserves of the benthic organisms. Consequently, if lipid and TOC content are the major determinants of BDE-99 bioaccumulation, calculation of BSAFs for BDE-99 should compensate for and eliminate the observed differences between treatments due to the addition of contaminated organic matter as well as between animal species. Here, however, the differences in bioaccumulation of BDE caused by organic matter quality or by different biological characteristics of the animals could not be explained by a normalization to TOC and to lipid content. On the contrary, when normalized to lipid and TOC content, Monoporeia had significantly lower BSAF values compared to the other two species. Moreover, for all studied species, the BSAF values for Tetraselmis treatments were all well above the theoretical maximum value of 1.7, which would not be exceeded if the equilibrium partitioning was the only determining factor (McFarland and Clarke, 1988). This indicates that treatment differences in bioaccumulation cannot be explained as purely driven by equilibrium partitioning in the present experiment. Instead, it is more likely that biological mechanisms such as selective feeding and other features of the organisms' feeding ecology and physiology influenced the exposure and bioavailability of sediment-associated contaminants or that these biological processes prevented the contaminants from reaching an equilibrium and were hence driving the accumulation in the animals above concentrations predicted by the equilibrium partitioning theory (EPT). This influence of biological processes has also been described in other published bioaccumulation studies. For example, a higher ingestion rate of nutritious organic material has been observed to lead to higher bioaccumulation of associated contaminants (Granberg and Forbes, 2006). Furthermore, differences in properties of the digestive fluid, intracellular digestion, gut retention time as well as elimination capacities have all been shown to influence the bioaccumulation of both HOCs and metals (Decho and Luoma, 1996; Chen and Mayer, 1999; Mayer et al., 2001; Griscom et al., 2002a).

\subsection{Species-specific contaminant bioaccumulation}

\subsubsection{Bioaccumulation of cadmium}


The polychaete Marenzelleria had the highest bioaccumulation of Cd followed by Macoma and Monoporeia. The observed differences for $\mathrm{Cd}$ may be due to differences in the feeding physiology and the ecology between the studied species as well as due to differences in exposure and bioavailability to dissolved $\mathrm{Cd}$ among species.

The speciation and association of Cd to inorganic and organic fractions will largely determine its bioavailability to organisms. When truly dissolved, uptake of $\mathrm{Cd}$ can be a result of diffusion through respiratory surfaces and the epidermis, whereas when it is associated with dissolved $(\mathrm{DOM})$ and particulate (POM) organic matter, the exposure is presumably higher through the diet (Wang and Fisher, 1999; Lee et al., 2000). However, when associated with DOM, the bioavailability of Cd may be limited (Voets et al., 2004). The speciation and bioavailability of metals also varies with chemical conditions in the sediment, such as $\mathrm{pH}$ (Heijerick et al., 2003), salinity and redox potential. In oxic conditions, most of the metal is associated with organic matter and inorganic structures such as iron and manganese oxides and hydroxides and clay minerals (Turner et al., 2004). However, in anoxic conditions, a key partitioning phase for cationic metals including $\mathrm{Cd}$ is the formation of less soluble metal sulfides (Di Toro et al., 1990), which may reduce the bioavailability.

Although all three species are surface feeders and to some extent selective feeders (Lopez and Levinton, 1987; Lindsay et al., 2004; Byrén et al., 2002), there may be differences between their feeding strategies such as their selectivity and feeding rate as well as their burrowing depth in the sediment that all contribute to differences in contaminant exposure and bioaccumulation. The burrowing amphipod Monoporeia affinis is mostly found in the sediment down to $4-5 \mathrm{~cm}$ (Ankar, 1977). It is an active particle bioturbator in the upper centimeters of the sediment. As deposit feeders the amphipods have been shown to preferentially feed on newly settled particles (Byrén et al., 2002). Their exoskeleton may also reduce their direct dermal exposure, i.e. a diffusive uptake through their skin. In a previous study, Eriksson Wiklund and Sundelin (2002) showed that dietary exposure was the main exposure route for metals, including $\mathrm{Cd}$, in this species. Macoma balthica is a facultative surface deposit- and suspension-feeding bivalve (Ólafsson, 1986), located at a similar depth (c. 3-5 cm deep) as Monoporeia in the sediment (Ankar, 1977). For Macoma, bioaccumulation of cadmium has previously been suggested to result mainly from ingestion of organic material (Lee et al., 2000, Griscom et al., 2002b). However, in a more recent study Luoma and Rainbow (2005) found that cadmium from dissolved sources accounted for $50 \%$ of total cadmium bioaccumulation. Although Macoma has a protective shell, relatively large surface areas of soft tissues, such as gills and siphons are exposed 
to contaminated water. Consequently, it is possible that direct exposure to dissolved $\mathrm{Cd}$ in pore water and in overlying water is greater for Macoma than for Monoporeia. The results of the present study also show a more pronounced accumulation of $\mathrm{Cd}$ in the clam Macoma than in the amphipod Monoporeia. The polychaete Marenzelleria constructs J-shaped, unbranched burrows down to $35 \mathrm{~cm}$ depth (Zettler et al., 1994). Marenzelleria can switch between various feeding modes depending on water currents and particle concentration in the water (Dauer et al., 1981). These polychaete worms have large surface areas compared to their mass and lack an exoskeleton or shell, which could lead to a relatively high diffusive uptake of Cd compared to Monoporeia and Macoma. Several polychaetes have been shown to accumulate $\mathrm{Cd}$ both in dissolved and particulate forms from both sediment and solution (Zhou et al., 2003; Geffard et al., 2005). Furthermore, Marenzelleria creates a respiratory current to irrigate their burrow (Dauer et al., 1981). This leads to a mobilization of dissolved Cd within the burrow structure and over the sediment-water interface which will further increase exposure of Marenzelleria to dissolved Cd in this experiment (Hedman et al., in press). Consequently, the higher accumulation of $\mathrm{Cd}$ observed in Marenzelleria than in Macoma and Monoporeia is probably in part explained by higher exposure and uptake of dissolved $\mathrm{Cd}$ in this species.

Furthermore, differences in digestive dissolution of ingested contaminated OM provide another explanation (of potentially equal importance) for the observed differences in $\mathrm{Cd}$ bioaccumulation among species. In a cross-phyletic study of contaminant solubilization by digestive fluids of benthic invertebrates, Mayer et al. (2001) observed significant differences in digestive fluid composition as well as contaminant bioavailability among species. In these studies polychaetes exhibited the strongest binding affinities for metals, whereas the digestive fluids of mollusks were intermediate in strength. Unpublished data also suggest that crustacean digestive fluids are closer to mollusks than to polychaetes (personal communication L. Mayer, Darling Marine Center, Univ. of Maine, USA). Consequently, there is a correlation between the observed differences in $\mathrm{Cd}$ bioaccumulation in the studied Baltic invertebrate species and species-specific metal solubilization observed by Mayer and co-workers. Thus, to summarize, it is likely that the observed differences in $\mathrm{Cd}$ bioaccumulation can be explained by a combination of selective feeding, dermal uptake and selective contaminant dissolution during gut passage.

\subsubsection{Bioaccumulation of BDE-99}

All three studied species accumulated BDE-99. This was in agreement with previous studies, where PBDEs have been shown to accumulate in several species (e.g. Gustafsson et al., 1999, 
Läppenen and Kukkonen, 2004). However, although the extent of bioaccumulation varied with different types of $\mathrm{OM}$ enrichment, no general difference was found between species. When enriched with the nutritious algae the bioaccumulation factors of BDE-99 were as high as 74.6, 43.7 and 42.3 for Marenzelleria, Monoporeia and Macoma respectively. This is relatively high compared to previous studies, e.g. the Baltic blue mussel Mytilus edulis exhibited a BAF of 14 and the oligochaete Lumbriculus variegatus had a mean BAF of 4.0 for BDE-99 (Gustafsson et al., 1999; Ciparis, 2005). Moreover, when normalized to TOC and lipid content, BSAF values were still relatively high compared to other studies and highest in the algae treatments, with a BSAF up to with 11.4 for Marenzelleria. However, for Macoma and Monoporeia, BSAF values were somewhat lower (up to 3.8 and 3.0 respectively) which can be compared to a mean BSAF of 3.0 for PBDE in Lumbriculus (Läppenen and Kukkonen, 2004) and an average of approximately 3.4 for nine different surface deposit feeders (Magnusson et al. 2003). Bioaccumulation of BDE99 has also been shown to be species-specific (Veltman et al., 2005). Although no general differences could be detected in bioaccumulation (BAFs) of BDE-99 between animals in the present study, their response to various OM differed. While Marenzelleria and Monoporeia had the lowest BDE-99 bioaccumulation in sediment treatments, Macoma bioaccumulated BDE-99 to a greater extent in sediment compared to lignin treatments. Moreover, when normalized to the lipid content of the animals (BSAF), the amphipod Monoporeia had the lowest bioaccumulation of BDE-99 of the three species.

For hydrophobic organic contaminants the primary exposure route of benthic invertebrates has been suggested to be through ingestion of contaminated food (Forbes et al., 1998; Weston et al., 2000). The flame retardant investigated in this study (BDE-99) is, like other HOCs, highly hydrophobic $\left(\log K_{\text {ow }} 7.13\right)$ and exhibits high OM affinity. This means that the dissolved fraction of BDE-99 in the microcosms was very low at the end of the exposure period (1-5\%). Thus, the primary exposure route for BDE-99 in this experiment is presumably through the diet for all three studied species. Hence, the lack of general differences in BDE-99 bioaccumulation among the studied benthic species suggests that no general differences in food exposure and bioavailability occurred. The only exception to this are the observed bioaccumulation differences when BDE-99 was associated with sediment particles, as discussed in the next section.

\subsection{The role of organic matter for bioaccumulation of contaminants}

In general, the nutritional quality of the added organic matter affected the bioaccumulation of both the metal and the flame retardant, with a higher bioaccumulation when associated with the 
labile OM, i.e. Tetraselmis. This is in agreement with previous studies, which have shown that assimilation efficiency and bioaccumulation of cadmium is greater from phytoplankton than from sediment (Griscom et al., 2002b) and wood fibers (Maloney, 1996). Similarly, several HOCs have been observed to exhibit enhanced bioaccumulation when associated with labile OM (Gunnarsson et al., 1999a, 1999b). Since all species studied in this experiment can be assumed to have a preference for labile algae compared to more refractory food sources (Christensen and Kanneworff, 1985; Jumars and Wheatcroft, 1989, Byrén et al., 2002), the higher BAFs for both $\mathrm{Cd}$ and BDE-99 in the algae treatments are probably to some extent caused by selective feeding. It is also possible that a combination of both a higher feeding rate in presence of labile OM and differences in bioavailability have resulted in a higher bioaccumulation of the contaminants when associated with algae, as discussed below.

For cadmium, there was a considerably lower bioaccumulation in the lignin treatment for all studied species compared to the Tetraselmis treatment. In addition, more or less no bioaccumulation was observed in sediment treatments for either Macoma or Monoporeia. In fact, no bioaccumulation was observed in Monoporeia unless cadmium was associated with the nutritious algae. This is in agreement with the findings of Sundelin and Eriksson (2001), who showed that, in an experiment where naturally-contaminated reduced sediment was reoxygenated, cadmium concentration was only slightly elevated in Monoporeia compared to sediment in one of three studied stations, which was heavily contaminated. The low bioavailability was explained by complexation of cadmium to chlorine ions, organic carbon and iron oxides and hydroxides (Sundelin and Eriksson, 2001). Although BAF values were generally much lower for lignin and sediment compared to algae treatments, animals exposed to cadmium associated with lignin generally had higher bioaccumulation factors than animals exposed to sediment. This accumulation pattern was consistent for all three species. Somewhat surprisingly, this result contradicts our hypothesis of decreased bioaccumulation in the order algae $>$ sediment $>$ lignin, owing to selective feeding on higher quality OM by the animals. There may be several ecological explanations for this difference, e.g. how the various species respond to different OM in terms of their physiology and ecology. However, one additional plausible explanation is that these observed differences are caused by differences in digestive dissolution among the studied OM sources. The green algae Tetraselmis was probably largely dissolved during gut passage, whereas sedimentary $\mathrm{OM}$ and presumably to an even higher degree lignin passed through the animals undigested. The dissolution of a contaminated substrate will make the associated contaminant more available for uptake, thereby explaining the higher bioaccumulation of $\mathrm{Cd}$ and PBDE in the Tetraselmis treatment. In a situation when ingested OM is incompletely dissolved during gut 
passage (as probably to a large extent is the case for lignin and sedimentary OM) contaminant dissolution and subsequent bioavailability will depend on a competition between dissolved solubilizing agents in the gut fluid and the binding strength of the particulate ingested substrates (Chen and Mayer, 1999). Thus, a higher affinity of Cd to ingested sediment than to ingested lignin could result in different bioavailability and subsequent bioaccumulation of $\mathrm{Cd}$ from these OM sources.

A further possible mechanism could be that differences in sorption capacities of contaminants to various OM sources resulted in different partitioning of contaminants in the microcosms. In this study, the partitioning of cadmium between the different compartments in the microcosm system showed that the major portion $(78-95 \%)$ of the added cadmium was detected in the surface sediment at the end of the experiment. However, there were substantial differences among OM treatments in the fraction cadmium remobilized to the overlying water (Hedman et al., in press). According to contaminant budget calculations on control cores without added animals, cores enriched with algae had a higher percentage of cadmium in the overlying water column (14\% of the total $\mathrm{Cd}$ activity found in whole core tube after 34 days) than cores enriched with lignin (9\%) or with sediment (5\%). This is in accordance with Gourlay et al. (2003) who suggested that highly degradable matter, such as fresh algae extracts, have low binding capacities for HOCs compared to less degradable substances such as humic substances and potentially also lignin and sedimentary OM. If the same is true for the algae in this experiment, the higher bioaccumulation observed for both contaminants in Tetraselmis treatments may also be a result of a higher degree of water uptake in these treatments. Furthermore, if cadmium is more easily desorbed from lignin than sediment, it would increase the bioavailability of the metal and could consequently result in a higher BAF value. Cadmium is probably found both in a truly dissolved phase in the water as well as associated with dissolved organic material (DOM) and particulate organic matter (POM) and these are most likely the bioavailable fractions. For BDE-99, on the other hand, no general difference was observed in bioaccumulation between sediment and lignin treatments. Similarly, no differences were observed in the concentration of BDE-99 in the overlying water fraction between OM treatments.

Although no general difference was found in bioaccumulation between lignin and sediment treatments for BDE-99, our results showed that bioaccumulation was higher in Macoma exposed to contaminated sediment than to contaminated lignin. This is the opposite of the results for $\mathrm{Cd}$, where Macoma had higher BAF in lignin treatments. There is no simple explanation for this observation. However, since the contaminants were added in the same OM treatment and with the assumption that the animals have the same feeding behavior in each experimental core, there 
must be differences in uptake routes and sorption capacities between the organic matter and cadmium and BDE-99. This is possibly an indication of differences in solubilization capacity of $\mathrm{Cd}$ and PBDE by Macoma digestive fluid in combination with the binding strength of the substrates (sensu Chen and Mayer, 1999). Moreover, Macoma differs from the other two species in their assimilation of organic matter (Decho and Luoma, 1996) and their ability to sort particles in their gills, where some particles are rejected and excreted as pseudo-feces (Decho and Luoma, 1991). Both of these mechanisms might have an influence on the bioaccumulation of Cd and BDE-99 from the various OM sources.

\subsection{Relevance for the Baltic Sea}

The Baltic Sea is characterized by variations in settling organic matter to the seafloor. There are distinct phytoplankton blooms in early spring and late summer. The present study has shown that the origin of OM settling to the seafloor can have a substantial effect on the bioaccumulation of associated contaminants. Thus, in the Baltic Sea, there may be seasonal differences in the bioaccumulation of contaminants, with an increased bioaccumulation by benthic deposit-feeders following spring and summer blooms, if these blooms have associated contaminants and if they reach the seabed. In the present study, the green alga Tetraselmis was used to simulate a nutritious organic source, analogous to a scenario of a phytoplankton bloom. The reason we chose Tetraselmis is that it is commercially available and thus easier to get than to collect algae from a natural bloom. However, its amino acid and fatty acid composition is similar to the composition of diatoms, which are the most common algae during a spring bloom in the Baltic Sea. During most parts of the year, settling organic matter that reaches the sediment surface of the Baltic Sea is of lower nutritional quality. For example, there are events of resuspension of sedimentary organic matter and inputs of organic matter from terrestrial sources. These types of inputs to the sediment were in this experiment simulated by the sediment and lignin treatments respectively. Compared with sediment and lignin, there was a significantly higher bioaccumulation of both $\mathrm{Cd}$ and BDE-99 in presence of nutritious organic material. In fact, for Monoporeia, Cd uptake did not accumulate beyond sediment concentrations unless the metal was associated with labile algae. A similar pattern was found for Macoma, whereas only a minor bioaccumulation was observed in animals exposed to lignin. Hence, cadmium contamination should be of particular environmental concern when it is associated with a nutritious and fresh organic source such as an algal bloom. This variation in bioaccumulation depending on OM quality may also have an impact on a larger spatial scale. During the last decades, the Baltic Sea has experienced increased eutrophication and primary production (HELCOM, 2005), which could result in increased fluxes of contaminants 
associated with algal debris to the seabed. The present study shows that this could increase the bioaccumulation of both metals and hydrophobic organic contaminants associated with $\mathrm{OM}$ in benthic deposit-feeding invertebrates. However, the findings of this study should at present only be used to discuss possible changes in the bioavailability of contaminants associated with newly settled OM. How changes in the type of OM reaching the seafloor will affect the fate and bioavailability of contaminants already present in the sediment will need to be assessed through experiments and modeling studies specially designed for this purpose.

Another important aspect of our results is the observed difference in bioaccumulation of cadmium between species, with the observed highest cadmium accumulation in Marenzelleria followed by Macoma and Monoporeia. Thus, depending on which species dominates the benthic community, the bioaccumulation and subsequent trophic transfer of cadmium from benthic invertebrates to higher trophic levels in the food web, e.g., fish and ultimately human consumers, may vary substantially. It is particularly interesting that the invasive species Marenzelleria showed the highest accumulation of cadmium of the three species in our study. This polychaete, recently introduced to the Baltic Sea with ballast water, has shown a great tolerance to hypoxic conditions (Schiedek, 1997) and a high colonization rate, and can therefore potentially outcompete other macrofaunal species in the Baltic Sea. Although its role as a food source for various fish species (and thereby its role for trophic transfer of contaminants) is not yet known in the Baltic Sea, Marenzelleria has recently been shown to increase the remobilization of contaminants from the sediment to the water column through bioturbation (Hedman et al., in press; Granberg et al., in prep). Hence, not only may contaminants bioaccumulate more in benthic communities dominated by this species, but the contaminants may also be transported to a greater extent into the food web.

\section{Acknowledgements}

We thank Mats Jansson's group at The Royal Institute of Technology (KTH) for their help with gamma activity measurements and the staff at the Askö Marine Laboratory for professional assistance in the field. This study was financed by grants from The Foundation for Baltic and East European Studies (grant no. 862/42/2005-9), the Stockholm Marine Research Centre (SMF) and The Swedish Research Council FORMAS (grant no. 216-2005-1424).

\section{References}


Ankar, S., 1977. The soft bottom ecosystem of the northern Baltic proper with special reference to the macrofauna. Contributions from the Askö laboratory, No 19. University of Stockholm, Sweden.

Bastrop, R., Blank, M., 2006. Multiple invasions - a polychaete genus enters the Baltic Sea. Biological Invasions 8, 1195-1200.

Bock, M.J., Miller, D.C. 1999. Particle selectivity, gut volume, and the response to a step change in diet for deposit-feeding polychaetes. Limnology and Oceanography 44, 1132-1138.

Blomqvist, S., Lundgren, L., 1996. A benthic sled for sampling soft bottoms. Helgolander Meeresuntersuchungen 50, 453-456.

Brafield, A.E., Newell, G.E., 1961. The behaviour of Macoma balthica (L.). Journal of the Marine Biological Association, U.K., 41, 81-87.

Byrén, L., Ejdung, G., Elmgren R., 2002. Comaring rate and depth of feeding in benthic depositfeeders: a test on two amphipods, Monoporeia affinis (Lindström) and Pontoporeia femorata Kröyer. Journal of Experimental Marine Biology and Ecology 281, 109-121.

Chen, Z., Mayer, L. M., 1999. Sedimentary metal bioavailability determined by the digesive constraints of marine deposit feeders: gut retention time and dissolved amino acids. Marine Ecology Progress Series 176, 139-151.

Christensen, H., Kanneworff, E., 1985. Sedimenting phytoplankton as major food source for suspension and deposit feeders in Øresund. Ophelia 24, 223-244.

Ciparis, S., Hale, R. C., 2005. Bioavailability of polybrominated diphenyl ether flame retardants in biosolids andspiked sediment to the aquatic oligochaete, Lumbriculus variegatus. Environmental Toxicology and Chemistry 24, 916-925.

Dauer, D. M., Maybury, C. A., Ewing, R. M., 1981. Feeding behavior and general ecology of several spionid polychaetes from the Chesapeake Bay. Journal of Experimental Marine Biology and Ecology 54, 21-38.

Decho, A. W., Luoma, S. N., 1991. Time-courses in the retention of food material in the bivalves Potamocorbula amurensis and Macoma balthica - significance to the absorption of carbon and chromium. Marine Ecology Progress Series 78, 303-314.

Decho, A. W., Luoma, S. N., 1996. Flexible digestion strategies and trace metal assimilation in marine bivalves. Limnology and Oceanography 41, 568-572.

Di Toro, D. M., Mahoney, J. D., Hansen, D. J., Scott, K. J., Hicks, M. B., Mayr, S. M., Redmond M. S., 1990. Toxicity of cadmium in sediments: The role of acid volatile sulfide. Environmental Toxicology and Chemistry 9, 1487-1502.

Di Toro, D. M., Zarba, C. S., Hansen, D. J., Berry, W. J., Swartz, R. C., Cowan, C. E., Pavlou, S. P., Allen, H. E., Thomas, N. A., Paquin, P. R., 1991. Technical basis for establishing sediment quality criteria for nonionic organic chemicals using equilibrium partitioning. Environmental Toxicology and Chemistry 10, 1541-1583.

Ejdung, G., Byrén, L., Elmgren, R., 2000. Benthic predator-prey interactions: evidence that adult Monoporeia affinis (Amphipoda) eat postlarval Macoma balthica (Bivalvia). Journal of Experimental Marine Biology and Ecology 253, 243-251.

Elmgren, R., Hill, C., 1997. Ecosystem functioning at low biodiversity- the Baltic example. In: Angel, M. V. (Ed), Marine Biodiversity - Patterns and Processes. Cambridge University Press, New York.

Eriksson Wiklund, A-K., Sundelin, B., 2002. Bioavailability of metals to the amphipod Monoporeia affinis: interactions with authigenic sulfides in urban brackish-water and freshwater sediments. Environmental Toxicology and Chemistry 21, 1219-1228.

Forbes, T. L., Forbes, V. E., Giessing, A., Hansen, R., Kure, L. K., 1998. Relative role of pore water versus ingested sediment in bioavailability of organic contaminants in marine sediments. Environmental Toxicology and Chemistry 17, 2453-2462. 
Gardner, W. S., Frez, W. A., Cichocki, E. A., 1985. Micromethod for lipids in aquatic invertebrates. Limnology and Oceanography 30, 1099-1105.

Geffard, A., Smith, B. D., Amiard-Triquet, C., Jeantet, A. Y., Rainbow, P. S., 2005. Kinetics of trace metal accumulation and excretion in the polychaete Nereis diversicolor. Marine Biology 147, 1291-1304.

Gourlay, C., Tusseau-Vuillemin, M-H., Garric, J., Mouchel, J-M., 2003. Effect of dissolved organic matter of various origins and biodegradabilities on the bioaccumulation of polycyclic aromatic hydrocarbons in Daphnia magna. Environmental Toxicology and Chemistry 22, 1288-1294.

Granberg, M. E., Forbes, T. L., 2006. Role of sediment organic matter quality and feeding history in dietary absorption and accumulation of Pyrene in the mud snail (Hydrobia ulvae). Environmental Toxicology and Chemistry 25, 995-1006.

Griscom, S. B., Fisher, N. S., 2004. Bioavailability of sediment-bound metals to marine bivalve molluscs: an overview. Estuaries 27, 826-838.

Griscom, S. B., Fisher, N. S., Aller, R. C., Lee, B-G., 2002 a. Effects of gut chemistry in marine bivalves on the assimilation of metals from ingested sediment particles. Journal of Marine Research 60, 101-120.

Griscom, S. B., Fisher, N. S., Luoma, S. N., 2002 b. Kinetic modeling of Ag, Cd, and Co bioaccumulation in the clam Macoma balthica: quantifying dietary and dissolved sources. Marine Ecology Progress Series 240, 127-141.

Gunnarsson, J. S., Sköld, M., 1999. Accumulation of polychlorinated biphenyls by the infaunal brittle stars Amphiura filiformis and A. chiajei: effects of eutrophication and selective feeding. Marine Ecology Progress Series 186, 173-185.

Gunnarsson, J. S., Schaanning, M. T., Hylland, K., Sköld, M., Eriksen, D. Ö., Berge, J. A., Skei, J., 1996. Interactions between eutrophication and contaminants. 3. Mobilization and bioaccumulation of benzo(a)pyrene from marine sediments. Marine Pollution Bulletin 33, 8089.

Gunnarsson, J. S., Granberg, M. E., Nilsson, H. C., Rosenberg, R., Hellman, B., 1999a. Influence of sediment-organic matter quality on growth and polychlorobiphenyl bioavailability in echinodernata (Amphiura filiformis). Environmental Toxicology and Chemistry 18, 15341543

Gunnarsson, J. S., Hollertz, K., Rosenberg, R., 1999b. Effects of organic enrichment and burrowing activity of the polychaete Neries diversicolor on the fate of tetrachlorobiphenyl in marine sediments. Environmental Toxicology and Chemistry 18, 1149-1156.

Gustafsson, K., Björk, M., Burreau, S., Gilek, M., 1999. Bioaccumulation kinetics of brominated flame retardants (Polybrominated diphenyl ethers) in blue mussels (Mytilus edulis). Environmental Toxicology and Chemistry 18, 1218-1224.

Hedges, J. I., Stern, J. H., 1983. Carbon and nitrogen determinations of carbonate-containing solids. Limnology and Oceanography 29, 657-663.

Hedman, J. E., Bradshaw, C., Thorsson, M. H., Gilek, M., Gunnarsson, J. S, In press. Fate of contaminants in Baltic Sea sediments: the role of bioturbation and settling organic matter. Marine Ecology Progress Series

Heijerick, D. G., Janssen, C. R., De Coen, W. M., 2003. The combined effects of hardness, pH, and dissolved organic carbon on the chronic toxicity of $\mathrm{Zn}$ to D. magna: Development of a surface response model. Archive of Environmental Contamination and Toxicology 44, 210217.

HELCOM, 2005. Nutrient pollution to the Baltic Sea in 2000. Baltic Sea Environment Proceedings 100. Helsinki Commission, 22 pp.

Jumars, P. A., Wheatcroft, R. A., 1989. Responses of benthos to changing food quality and quantity, with focus on deposit feeding and bioturbation. In: Berger, W.H., Smetacek, V.S., Wefer, G. (eds) Productivity of the ocean: present and past. John Wiley and Sons Ltd, New York, pp 235-253. 
Kukkonen, J. V. K., Landrum, P. F., Mitra, S., Gossiaux, D. C., Gunnarsson, J., Weston, D., 2003. Sediment characteristics affecting desorption kinetics of select PAH and PCB congeners for seven laboratory spiked sediments. Environmental Science and Technology 37, 4656-4663.

Lake, J. L., Rubenstein, H. L., Lake, C. A., Heltshe, J., Pavignano, S., 1990. Equilibrium partitioning and bioaccumulation of sediment-associated contaminants by infaunal organisms. Environmental Toxicology and Chemistry 9, 1095-1106.

Larsson, U., Hobro, R., Wulff, F., 1986. Dynamics of a phytoplankton spring bloom in a coastal area of the northern Baltic Proper. Contributions from the Askö Laboratory, University of Stockholm, Sweden 30, 1-32.

Lee, R. F., 2002. Bioavailability, biotransformation, and fate of organic contaminants in estuarine animals. In Newman, M. C,. Roberts Jr, M, H., Halem R, C., (Eds), Coastal and estuarine risk assessment. Lewis Publishers, London.

Lee, B-G., Griscom, S. B., Lee, J-K., Choi, H. J., Koh, C-H., Luoma, S. N., Fisher, N. S., 2000. Influences of dietary uptake and reactive sulfides on metal bioavailability from aquatic sediments. Science 287, 282-284.

Lindsay, S. M., Riordan, T. J., Forest, D., 2004. Identification and activity-dependent labeling of peripheral sensory structures on a spionid polychaete. Biological Bulletin 206, 65-77.

Luoma, S. N., Rainbow, P. S., 2005. Why is metal bioaccumulation so variable? Biodynamics as a unifying concept. Environmental Science and Technology 39, 1921-1931.

Lopez, G. R., Levinton, J. S., 1987. Ecology of deposit feeding animals in marine sediments. The Quarterly Review of Biology 62, 235-260.

Läppenen, M. T., Kukkonen, J. V. K., 2004. Toxicokinetics of sediment-associated polybrominated diphenyl ethers (Flame retaradants) in benthic invertebrates (Lumbriculus variegatus, Oligochaeta). Environmental Toxicology and Chemistry 23, 166-172.

Magnusson, K., Agrenius, S., Ekelund, R., 2003. Distribution of a tetrabrominated diphenyl ether and its metabolites in soft bottom sediment and macro fauna species. Marine Ecology Progress Series 255, 155-170.

Maloney, J., 1996. Influence of organic enrichment on the partitioning and bioavailability of cadmium in a microcosm study. Marine Ecology Progress Series 144, 147-161.

Mayer, L. M., Chen, Z., Findlay, R. H., Fang, J. S., Sampson, S., Self, R. F. L., Jumars, P. A., Quetel, C., Donard, O. F. X., 1996. Bioavailability of sedimentary contaminants subject to deposit-feeder digestion. Environmental Science and Technology 30, 2641-2645.

Mayer, L. M., Weston, D. P., Bock, M. J., 2001. Benzo[a]pyrene and zinc solubilization by digestive fluids of benthic invertebrates - a cross-phyletic study. Environmental Toxicology and Chemistry 20, 1890-1900.

McFarland, V. A., Clarke, J. U., 1988. Testing bioavailability of polychlorinated biphenyls from sediments using a two-level approach. Proceedings, Water quality R\&D: Successful Bridging Between Theory and Application, New Orleans, LA, USA, 25-27, pp 220-229.

Ólafsson, E. B., 1986. Density dependence in suspension-feeding and deposit-feeding populations of the bivalve Macoma balthica: a field experiment. Journal of Animal Ecology 55, 517-526.

Schiedek, D., 1997. Marenzelleria viridis (Verrill, 1873) (Polychaeta), a new benthic species within European coastal waters - Some metabolic features. Journal of Experimental Marine Biology 211, 85-101.

Schlekat, C. E., Lee, B-G., Luoma, S. N., 2002. Dietary metal exposure and toxicity to aquatic organisms: implications for Ecological Risk Assessment. In Newman, M. C,. Roberts Jr, M. H., Hale, R. C., (Eds), Coastal and estuarine risk assessment. Lewis publishers, London.

Sundelin, B., Eriksson, A-K., 2001. Mobility and bioavailability of trace metals in sulfidic coastal sediments. Environmental Toxicology and Chemistry 20, 748-756.

Tittlemier, S. A., Halldorson, G. A., Stern, G. A., Tomy, G. T., 2002. Vapor pressure, aqueous solubilities, and Henry's laws constant of some brominated flame retardants. Environmental Toxicology and Chemistry 21, 1804-1810. 
Turner, A., Millward, G. E., 2002. Suspended particles: their role in estuarine biogeochemical cycles. Estuarine, Coastal and Shelf Science 55, 857-883.

Turner, A., Millward, G. E., Le Roux, S. M., 2004. Significance of oxides and particulate organic matter in controlling trace metal partitioning in a contaminated estuary. Marine Chemistry $88,179-192$.

Wang, W-X., Fisher, N. S., 1999. Delineating metal accumulation pathways for marine invertebrates. The Science of the Total Environment 30, 459-472.

Wang, W-X., Wong, R. C. K., 2003. Combined effects of food quantity and quality on Cd, Cr and $\mathrm{Zn}$ assimilation to the green mussel Perna viridis. Journal of Experimental Marine Biology and Ecology 290, 49-69.

Veltman, K., Hendriks, J., Huijbregts, M., Leonards, P., Van den Heuvel-Greve, M., Vethaak, D., 2005. Accumulation of organochlorines and brominated flame retardants in estuarine and marine food chains: Field measurements and model calculations. Marine Pollution Bulletin 50, 1085-1102.

Weston, D. P., Penry, D. L., Gulmann, L. K., 2000. The role of ingestion as a route of contaminant bioaccumulation in a deposit-feeding polychaete. Archives of Environmental Contamination and Toxicology 38, 446-454.

Voets, J., Bervoets, L., Blust, R., 2004. Cadmium bioavailability and accumulation in the presence of humic acid to the zebra mussel, Dreissena polymorpha. Environmental Science and Technology 38, 1003-1008.

Zettler, M. L., Bochert, R., Bick, A., 1994. Röhrenbau und vertkalverteilung von Marenzelleria viridis (Polychaeta: Spionidae) in einem inneren Kustengewässer der sudlichen Ostsee. Rostock Meeresbiol Beitr 2, 215-225.

Zettler, M. L., Bick, A., Bockert, R., 1995. Distribution and population dynamics of Marenzelleria viridis (Polychaeta: Spionidae) in coastal water of southern Baltic. Archive of Fishery and Marine Research 42, 209-224.

Zhou, Q. X,. Rainbow, P. S., Smith, B. D., 2003. Tolerance and accumulation of the trace metals zinc, copper and cadmium in three populations of the polchaete Nereis diversicolor. Journal of the Marine Biological Association of the United Kingdom 83, 65-72. 


\section{Tables and figures}

EFFECTS OF SETTLING ORGANIC MATTER ON THE BIOACCUMULATION OF CADMIUM AND BDE-99 BY BALTIC SEA BENTHIC INVERTEBRATES

Table 1. Animal additions to the experimental core tubes presented as added individuals per core as well as estimated biomass per $\mathrm{m}^{2}$. Animals were added to represent typical field densities in the Baltic Sea.

\begin{tabular}{|c|c|c|c|c|c|c|}
\hline Animal & $\begin{array}{l}\text { Indiv. } \\
\text { per core }\end{array}$ & $\begin{array}{l}\text { Biomass } \\
\text { per core } \\
(\mathrm{g} \mathrm{dw})\end{array}$ & Indiv. $\mathbf{m}^{-2}$ & $\begin{array}{l}\text { Biomass. } \mathrm{m}^{-2} \\
(\mathrm{~g} \mathrm{dw})\end{array}$ & Feeding strategy & $\begin{array}{l}\text { Approximate } \\
\text { burial depth } \\
\text { (cm) }\end{array}$ \\
\hline Monoporeia affinis & 15 & 0.011 & 3000 & 2.2 & $\begin{array}{l}\text { Surface deposit } \\
\text { feeder }^{1}\end{array}$ & $1-5^{1,2}$ \\
\hline Macoma balthica & 5 & 0.24 & 1000 & 47.8 & $\begin{array}{l}\text { Surface deposit/ } \\
\text { suspension feeder }\end{array}$ & $3-5^{1,2}$ \\
\hline Marenzelleria & 7 & 0.072 & 1400 & 14.3 & $\begin{array}{l}\text { Surface deposit/ } \\
\text { Suspension feeder }\end{array}$ & $7.5-35^{3,4}$ \\
\hline
\end{tabular}

${ }^{1}$ Ankar (1977) ${ }^{2}$ Brafield and Newell (1961) ${ }^{3}$ Zettler et al. (1994) ${ }^{4}$ Dauer et al. (1981) 
Table 2. Nutritional characteristics of the three types of organic matter (OM). Amounts of TOC added per core tube in the different treatments and nominal concentrations of ${ }^{109} \mathrm{Cd}$ and ${ }^{14}$ C-BDE-99. TN: total nitrogen, TC: total carbon, TOC: total organic carbon. Percentages are all based on dry weights.

\begin{tabular}{|c|c|c|c|c|c|c|c|c|}
\hline \multirow[b]{2}{*}{ OM Treatment } & \multicolumn{4}{|c|}{ OM quality characteristics } & \multicolumn{2}{|c|}{ TOC added } & \multicolumn{2}{|c|}{$\begin{array}{c}\text { Nominal } \\
\text { concentrations of } \\
\text { contaminants }\end{array}$} \\
\hline & $\begin{array}{c}\text { Nutritional } \\
\text { quality }\end{array}$ & $\% \mathrm{TN}$ & $\% \mathrm{TC}$ & $\% \mathrm{TOC}$ & $\begin{array}{c}\text { TOC core }^{-1} \\
(\mathrm{mg})\end{array}$ & $\begin{array}{c}\text { TOC m } \\
\text { (g) }\end{array}$ & $\begin{array}{l}{ }^{14} \mathrm{C}^{1} \text { core }^{-1} \\
\text { (Bq) }\end{array}$ & $\begin{array}{c}{ }^{109} \mathrm{Cd} \mathrm{core}^{-1} \\
(\mathrm{~Bq})\end{array}$ \\
\hline Tetraselmis (Ts) & High & 5.0 & 40.2 & 32.2 & 48.56 & 9.7 & $2.7 * 10^{4}$ & $1.2 * 10^{5}$ \\
\hline Lignin (Ln) & Very low & 0.1 & 66.4 & 62.8 & 48.14 & 9.6 & $2.7 * 10^{4}$ & $1.2 * 10^{5}$ \\
\hline Sediment (Se) & Low & 0.3 & 1.77 & 1.4 & 48.34 & 9.7 & $2.7 * 10^{4}$ & $1.2 * 10^{5}$ \\
\hline
\end{tabular}


Table 3. Contaminant concentrations in sediment $(0-1 \mathrm{~cm})$ and contaminant accumulation in animals at the end of the experiment. BAF values are calculated on dry weight basis, and BSAFs are normalized to lipid and TOC concentrations of animals and sediment, respectively. Concentrations of Cd-109 and BDE-99 in sediment and animals are given as mean \pm std. BAF and BSAF are presented as geometric means. Note that for presentation reasons only + std is given for BAF and BSAF. Negative std are always somewhat smaller for geometric means. Mo: Monoporeia affinis, Mc: Macoma balthica, Mz: Marenzelleria, Ts: Tetraselmis, Ln: lignin, Se: sediment, TOC: total organic carbon, TN: total nitrogen.

\begin{tabular}{|c|c|c|c|c|c|c|c|c|c|c|c|}
\hline \multirow{3}{*}{\multicolumn{2}{|c|}{ Treatment }} & \multicolumn{4}{|c|}{ Sediment } & \multicolumn{6}{|c|}{ Animals } \\
\hline & & \multirow{2}{*}{$\begin{array}{c}\text { TOC } \\
\%\end{array}$} & \multirow{2}{*}{$\begin{array}{c}\mathrm{TN} \\
\%\end{array}$} & \multirow{2}{*}{$\begin{array}{c}\mathrm{Cd}-109 \\
\mathrm{kBq}^{-1} \\
\mathrm{gdw}^{-1}\end{array}$} & \multirow{2}{*}{$\begin{array}{c}\text { BDE-99 } \\
\mathrm{kBq}^{-1} \\
\mathrm{gdw}^{-1}\end{array}$} & \multirow{2}{*}{$\begin{array}{l}\text { Lipid } \\
\%\end{array}$} & \multicolumn{2}{|c|}{ Cd-109 } & \multirow[b]{2}{*}{$\begin{array}{c}\mathrm{kBq} \\
\mathrm{gdw}^{-1}\end{array}$} & \multirow{2}{*}{$\begin{array}{c}\text { BDE-99 } \\
\text { BAF }\end{array}$} & \multirow[b]{2}{*}{ BSAF } \\
\hline & & & & & & & $\begin{array}{l}\mathrm{kBq} \\
\mathrm{gdw}^{-1}\end{array}$ & BAF & & & \\
\hline Mo & Ts & 1.9 & 0.3 & $2.8 \pm 0.5$ & $1.0 \pm 0.1$ & 27.1 & $7 \pm 1$ & $2+1$ & $44 \pm 12$ & $44+9$ & $3.0+0.6$ \\
\hline Mo & Ln & 1.8 & 0.3 & $2.7 \pm 0.4$ & $0.7 \pm 0.1$ & 27.1 & $3 \pm 2$ & $1+1$ & $6 \pm 4$ & $7+8$ & $0.5+0.5$ \\
\hline Mo & $\mathrm{Se}$ & 1.8 & 0.3 & $4.8 \pm 0.3$ & $1.2 \pm 0.0$ & 27.1 & $1.6 \pm 0.8$ & $0.3+0.3$ & $7 \pm 2$ & $5+2$ & $0.4+0.1$ \\
\hline Mc & Ts & 1.7 & 0.3 & $1.7 \pm 0.2$ & $0.6 \pm 0.2$ & 15.5 & $8 \pm 2$ & $4+1$ & $23 \pm 5$ & $42+16$ & $4+1$ \\
\hline $\mathrm{Mc}$ & $\mathrm{Ln}$ & 1.5 & 0.2 & $1.4 \pm 0.7$ & $0.4 \pm 0.2$ & 15.5 & $2.3 \pm 0.8$ & $1.6+0.4$ & $3 \pm 1$ & $7+3$ & $0.7+0.3$ \\
\hline Mc & $\mathrm{Se}$ & 1.5 & 0.2 & $2.6 \pm 0.3$ & $0.6 \pm 0.3$ & 15.5 & $2.2 \pm 0.6$ & $0.8+0.3$ & $8 \pm 1$ & $16+10$ & $2+1$ \\
\hline $\mathrm{Mz}$ & Ts & 1.5 & 0.2 & $1.1 \pm 0.3$ & $0.5 \pm 0.2$ & 10.2 & $10 \pm 1$ & $9+2$ & $34 \pm 6$ & $75+36$ & $12+6$ \\
\hline $\mathrm{Mz}$ & $\mathrm{Ln}$ & 1.7 & 0.2 & $2.0 \pm 0.7$ & $0.5 \pm 0.2$ & 10.2 & $3.6 \pm 0.4$ & $2+1$ & $6 \pm 1$ & $6+9$ & $1+1$ \\
\hline $\mathrm{Mz}$ & $\mathrm{Se}$ & 1.6 & 0.3 & $2.9 \pm 0.4$ & $1.2 \pm 0.4$ & 10.2 & $3 \pm 1$ & $1.1+0.6$ & $12 \pm 8$ & $7+4$ & $1.3+0.7$ \\
\hline
\end{tabular}


Table 4. Estimated adjusted BAFs for Cd-109 and BDE-99 and possible bias (\%) of measured BAFs in Marenzelleria because of undigested sediment remaining in the digestive system. The percentage BAF bias describes the percentage difference between measured BAF and adjusted BAF (geometric means). Note that for presentation reasons only + std is given for BAF. Negative std are always somewhat smaller for geometric means. Mz: Marenzelleria, Ts: Tetraselmis, Ln: lignin, Se: sediment.

\begin{tabular}{|c|c|c|c|c|c|c|}
\hline \multirow[b]{2}{*}{ Treatment } & \multicolumn{3}{|c|}{ Cd-109 bioaccumulation } & \multicolumn{3}{|c|}{ BDE-99 bioaccumulation } \\
\hline & $\mathrm{BAF}$ & $\begin{array}{l}\text { Adjusted } \\
\text { BAF }\end{array}$ & $\begin{array}{l}\text { Estimated } \\
\text { BAF bias }\end{array}$ & BAF & $\begin{array}{c}\text { Adjusted } \\
\text { BAF }\end{array}$ & $\begin{array}{l}\text { Estimated } \\
\text { BAF bias }\end{array}$ \\
\hline $\mathrm{Mz}$ & $9+2$ & $13+3$ & $-41 \%$ & $75+36$ & $105+56$ & $-39 \%$ \\
\hline $\mathrm{Mz}$ & $2+1$ & $2+1$ & $-20 \%$ & $6+9$ & $8+12$ & $-36 \%$ \\
\hline $\mathrm{Mz}$ & $1.1+0.6$ & $1+1$ & $-2 \%$ & $7+4$ & $10+5$ & $-39 \%$ \\
\hline
\end{tabular}




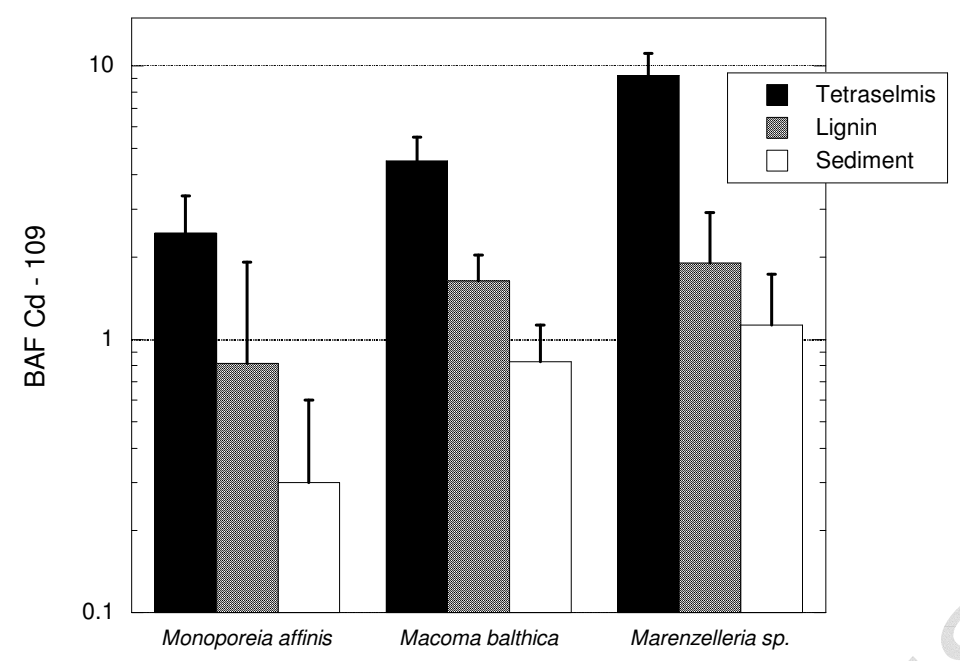

Fig. 1. Bioaccumulation factors (BAF) presented as geometric means for ${ }^{109} \mathrm{Cd}$ in the three different species of benthic invertebrates (M. affinis, M. balthica and Marenzelleria) exposed to three different types of contaminated organic matter (Tetraselmis, lignin and sediment). BAF is calculated on a dry weight basis and error bars show standard deviations. 


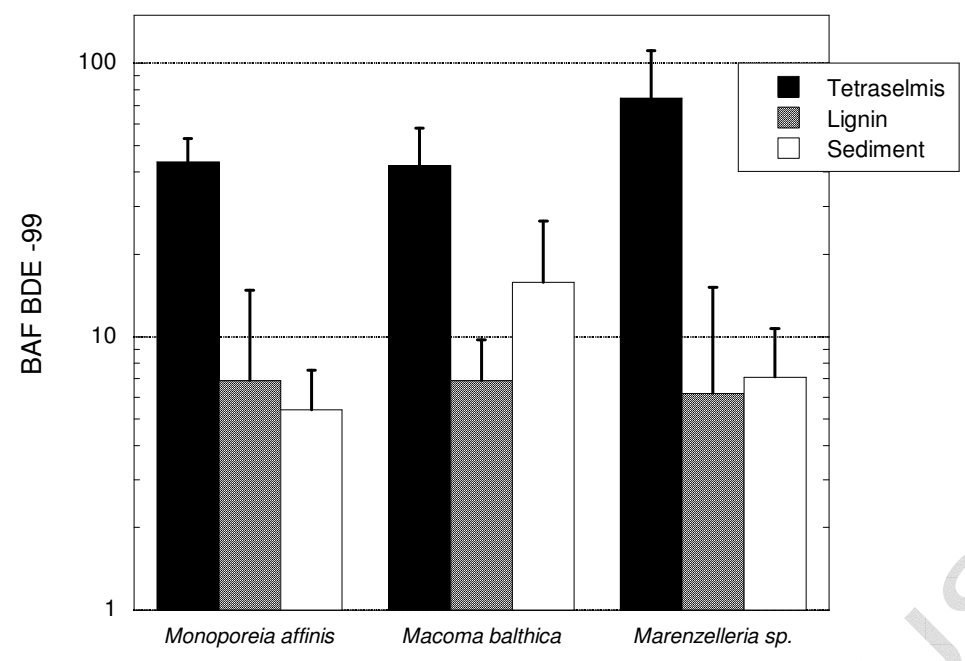

Fig. 2. Bioaccumulation factors (BAF) presented as geometric means for BDE-99 in the three different species of benthic invertebrates (M. affinis, M. balthica and Marenzelleria) exposed to three different types of contaminated organic matter (Tetraselmis, lignin and sediment). BAF is calculated on a dry weight basis and error bars show standard deviations. 


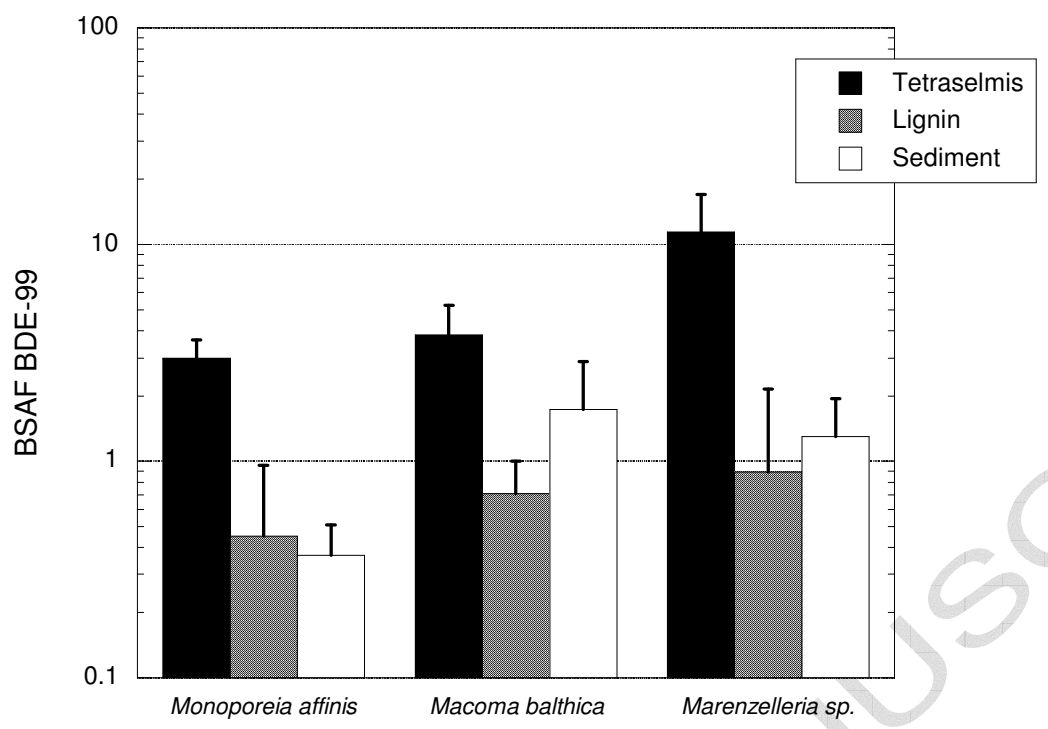

Fig. 3. Biota sediment accumulation factors (BSAF) presented as geometric means for BDE-99 in the three different species of benthic invertebrates (M. affinis, M. balthica and Marenzelleria) exposed to three different types of organic matter enrichment (Tetraselmis, lignin and sediment). BSAF is calculated on a dry weight basis and error bars show standard deviations. 